Syntax Fusion: Jurnal Nasional Indonesia

e-ISSN: 2775-4440

Vol. 1, No. 10, Oktober 2021

\title{
PEMBINAAN DAN PEMENUHAN HAK BAGI NARAPIDANA HUKUMAN MATI KASUS TERORISME
}

\author{
Mu'arrif Nur Qowi, Mitro Subroto \\ Politeknik Ilmu Pemasyarakatan, Indonesia \\ Email: qowi2203@gmail.com, mitro.suroto@gmail.com
}

\begin{abstract}
Abstrak
Dalam sistem pemasyarakatan pidana penjara diberlakukan dengan tetap menjunjung tinggi harkat dan martabat seorang WBP sebagai manusia seutuhnya. Maksud dari penerapan perlakuan tersebut yaitu selalu menempatkan posisi narapidana bukan hanya sekedar objek, akan tetapi juga subjek dalam suatu proses pembinaan. Pembinaan yang dilakukan di dalam lapas bagi narapidana haruslah diperhatikan dengan saksama dengan meninjau kondisi setiap individu pelaku kejahatan, pengaruh keluarga maupun pengaruh dari lingkungan sosialnya. Terkhusus dalam hal penanganan permasalahan bagi narapidana tindak pidana terorisme saat ini adalah belum terintegrasinya penanganan bagi pelaku tindak pidana terorisme tersebut. Dalam pelaksanaan penelitian, peneliti menggunakan metode deskriptif dengan pendekatan penelitian kualitatif yaitu melukiskan atau menggambarkan keadaan objek dan subjek, baik lembaga, masyarakat, dan lain sebagainya. Seiring berkembangnya kasus saat ini, disusul adanya narapidana teroris, oleh karena itu diperlukan suatu pendekatan dan pola pembinaan khusus. Pembinaan terhadap narapidana teroris ini harus disesuaikan dengan ketentuan dan aturan yang berlaku serta Peraturan Pemerintah Republik Indonesia Nomor 99 Tahun 2012 tentang Perubahan Kedua Atas Peraturan Pemerintah Nomor 32 Tahun 1999 tentang Syarat dan Tata Cara Pelaksanaan Hak Warga Binaan Pemasyarakatan yang lebih menekankan kepentingan keamanan, ketertiban umum dan rasa keadilan masyarakat.
\end{abstract}

Kata Kunci: Pembinaan; Narapidana; Terorisme

Diterima: 15-09-2021 Direvisi: 15-10-2021 Disetujui: 18-10-2021

\section{Pendahuluan}

Penyelenggaraan sistem pemasyarakatan adalah kegiatan yang dilakukan sebagai bentuk Warga Binaan Pemasyarakatan (WBP) supaya bisa menjadi manusia seutuhnya, memiliki kesadaran akan kesalahan, perbaikan diri, dan tidak mengulangi tindak pidana sehingga dapat diterima kembali oleh lingkungan masyarakat, kembali aktif dan ikut serta berperan dalam kegiatan pembangunan, dapat hidup secara sebagaimana adanya sebagai warga negara yang baik dan bertanggung jawab. Sistem ini dilaksanakan guna 
membentuk WBP yang mampu berbaur dengan sehat bersama masyarakat melalui binaan dan bimbingan oleh Lembaga Pemasyarakatan (Lapas).

Dalam sistem pemasyarakatan pidana penjara diberlakukan dengan tetap menjunjung tinggi harkat dan martabat seorang WBP sebagai manusia seutuhnya. Maksud dari penerapan perlakuan tersebut yaitu selalu menempatkan posisi narapidana bukan hanya sekedar objek, akan tetapi juga subjek dalam suatu proses pembinaan (A. Ali, 2008). Sasarannya mengembalikan narapidana kembali di tengah kehidupan masyarakat sebagai orang yang baik, berguna, dan bertanggung jawab (resosialisasi terpidana).

Sebuah usaha pembinaan dan pembimbingan baik itu pembimbingan kepribadian maupun pembimbingan kemandirian menjadi inti utama dari kegiatan sistem pemasyarakatan, di mana kedua jenis pembimbingan itu mempunyai fokus arah dan tujuan masing-masing, yaitu pembimbingan kepribadian mengarah dan berfokus pada diri pribadi WBP atau disebut hidup dan kehidupan dari WBP tersebut. Sedangkan, Pembimbingan kemandirian adalah cara dan program agar WBP dapat memiliki keahlian dan keterampilan yang dapat dijadikannya sebagai bekal saat dikembalikan di tengah masyarakat atau disebut sebagai pengupayaan pengembalian penghidupan WBP nantinya. Kegiatan sistem pemasyarakatan inilah yang menjadi sebuah sarana cara memperlakukan atau bentuk perlakuan dengan cara baru bagi narapidana sebagai wujud dukungan pola upaya baru pelaksanaan pidana penjara demi tercapainya keberhasilan peran, tugas dan fungsi negara mengeluarkan narapidana menjadi anggota bagian dari masyarakat kembali. Peranan dan keterlibatan masyarakat sangat dibutuhkan dalam perlakuan cara baru terhadap narapidana dalam pemasyarakatan. Kemudian muncullah doktrin bahwasannya narapidana tidak dapat diasingkan kehidupannya dari pergaulan masyarakat (Sumarwoto, 2020).

Terdapat tiga tahapan pelaksanaan pembinaan terhadap narapidana, yaitu tahap awal, tahap lanjutan, dan tahap akhir. Pemberian pembinaan tahap awal ini mulai diberikan kepada narapidana sejak yang bersangkutan sudah menyandang status narapidana sampai dengan 1/3 (satu per tiga) dari masa pidana. Ada 2 (dua) fase pembinaan tahap lanjutan, yaitu 1) Tahap lanjutan pertama yang berlaku sejak masa berakhirnya pembinaan tahap awal sampai dengan $1 / 2$ (satu per dua) dari masa pidana; 2) Tahap lanjutan kedua, mulai dari berakhirnya pembinaan tahap lanjutan pertama sampai dengan 2/3 (dua per tiga) dari masa pidana. Kemudian baru dilaksanakannya pembinaan tahap akhir yang dilakukan sejak dari usianya tahap lanjutan hingga usainya masa pidana narapidana terkait. Pengalihan tahapan pembinaan dengan melihat dan meninjau hasil penelitian masyarakat (litmas) yang sebelumnya dilakukan melalui proses sidang tim pengamat pemasyarakatan (Syaiful Bakhri, 2014).

Berdasarkan Undang-undang Nomor 12 Tahun 1995 tentang Pemasyarakatan, sistem pemasyarakatan adalah suatu tatanan terkait arah dan batas serta tata cara pembinaan warga binaan pemasyarakatan yang berdasarkan Pancasila dan berlangsung terpadu antara pembina, yang dibina, dan masyarakat guna meningkatkan kualitas warga binaan pemasyarakatan agar mereka menyadari kesalahan, melakukan perbaikan diri dan 
tidak mengulang tindak pidana, sehingga dapat disambut kembali di lingkungan masyarakat, ikut serta dalam kegiatan pembangunan, dan dapat hidup sewajarnya sebagai warga negara yang baik dan bertanggung jawab. Pembinaan yang dilakukan di dalam lapas bagi narapidana haruslah diperhatikan dengan saksama dengan meninjau keadaan si pelaku tindak kejahatan, pengaruh keluarga maupun pengaruh dari lingkungan sosialnya.

Dilakukannya kegiatan penelitian kemasyarakatan dengan meninjau dan memperhatikan segala pertimbangan yang ada hingga diperbolehkannya hasil, maka akan didapatkan sebuah klasifikasi yang tepat sebagai model pembinaan dan penempatan seorang narapidana sesuai dengan kebutuhan/keperluan dan resikonya. Oleh karena itu, sebagai bentuk pemenuhan syarat untuk tercapainya efektivitas atau berhasil tidaknya pencapaian tujuan pelaksanaan pembinaan maka diperlukan model perlakuan khusus sesuai dengan kebutuhan dan tingkat risiko masing-masing narapidana. Apabila pencapaian sesuai dengan tujuan yang diharapkan dan yang telah ditentukan maka model pembinaan atau model perlakuan khusus dapat dikatakan efektif untuk diterapkan (Chazawi, 2002).

Namun, pada realitas kejadian nyatanya belum semua dari program penanganan dan pembinaan itu mampu menjawab serta belum mengatasi pemenuhan kebutuhan dan persoalan atau permasalahan yang dihadapi oleh narapidana. Sehingga, inilah yang mengakibatkan muncul terjadinya perilaku yang melanggar peraturan di dalam Lapas juga perilaku yang cenderung agresif pada narapidana. Terkhusus dalam hal penanganan permasalahan bagi narapidana tindak pidana terorisme saat ini adalah belum terintegrasinya penanganan bagi pelaku tindak pidana terorisme tersebut, dalam artian bahwa penanganan bisa saja berhenti saat pelaku tertangkap dan dijatuhi pidana. Konteks permasalahan kategori pembinaan narapidana dalam kasus ini tidak dapat dipandang sama dengan narapidana-narapidana lainnya, seperti pelaku tindak pidana narkoba atau tindak pidana kriminal korupsi, tetapi dibutuhkannya sebuah model cara baru atau sebuah perlakuan khusus untuk menanganinya.

Narapidana tindak pidana terorisme akan dipisahkan dan ditempatkan pada sel terpisah dari narapidana tindak pidana lain bahkan dapat satu sel terisi oleh satu Napiter saja. Hal ini guna mencegah adanya penghasutan dan pemengaruhan yang dibawa oleh napiter pada narapidana lain. Rahim radikalisme dan terorismelah yang melahirkan narapidana teroris. Dikatakan rahim karena apabila sudah benar-benar terpengaruh dan secara sedikit demi sedikit terpupuk maka akan tertanam pada diri yang mempercayainya atau bahkan berlebihan dengan memunculkan perspektif yang berbeda pada tujuan awalnya. Radikal dalam arti sempit memiliki makna akar, sumber atau asal-muasal dari sesuatu. Dalam arti luas, radikal adalah prinsip, hal-hal mendasar dan fundamental yang berupa pokok soal yang esensial atas terjadinya bermacam gejala yang tidak biasanya atau tidak sewajarnya. Namun, sebenarnya radikal bermakna netral, radikal dapat bermakna positif atau negatif bergantung pada konteks lingkup ruang dan waktu yang melatarbelakangi terjadinya suatu gejala tersebut. Narapidana tindak pidana lain kemungkinan akan menyesali perbuatannya, menyadari dan mengakui perbuatannya 
yang salah dan melanggar hukum itu, sehingga menyebabkan dirinya harus menjalani hukuman pemidanaan sebagai bentuk tebusan atas kesalahan yang telah diperbuat. Lain halnya dengan narapidana teroris (M.K. Dermawan, 2001).

Menurut Pasal 1 Ayat (2) Undang-Undang Nomor 5 Tahun 2018 Tentang Pemberantasan Tindak Pidana Terorisme, yang dimaksud dengan Terorisme adalah perbuatan yang menggunakan kekerasan atau ancaman kekerasan yang mendatangkan kondisi teror atau rasa takut dalam jangkauan yang luas, yang dapat mengakibatkan adanya korban yang bersifat massal, dan/atau menciptakan kerusakan atau kehancuran terhadap objek penting, Lingkungan hidup, fasilitas publik, atau fasilitas internasional dengan motif ideologi, politik, atau gangguan keamanan.

Dalam undang-undang tersebut disebutkan, kekerasan yang dimaksud sebagai: setiap bentuk perlakuan, perbuatan yang menyalahgunakan kekuatan fisik dengan atau tanpa mempergunakan sarana dan prasarana secara melawan dan menentang hukum yang menimbulkan bahaya dan korban bagi badan, jiwa, nyawa, dan kemerdekaan orang, termasuk membuat orang pingsan atau tidak sadarkan diri dan tidak berdaya."

Selanjutnya ancaman kekerasan dijelaskan sebagai: "setiap bentuk perlakuan, perbuatan secara melawan dan menentang hukum berupa tulisan, gambar, ucapan, simbol, atau gerakan tubuh, baik dengan maupun tanpa menggunakan sarana dalam bentuk elektronik atau nonelektronik yang bisa menumbuhkan rasa takut bagi orang atau masyarakat luas atau membatasi ruang gerak dan kebebasan hakiki seseorang atau masyarakat."

Bahan peledak diartikan sebagai: "Segala bentuk bahan yang dapat meledak, semua jenis mesiu, bom pembakar, bom, granat tangan, ranjau, atau segala bahan peledak dari bahan kimia ataupun bahan lain yang digunakan untuk menimbulkan ledakan."

Telah diketahui bersama bahwasannya tindak pidana terorisme yang terjadi di Indonesia selama ini termasuk dalam kategori/golongan kejahatan serius yang sangat membahayakan bagi kehidupan dan keberlangsungan ideologi negara, keamanan dan ketertiban negara, kedaulatan negara, nilai-nilai kemanusian, dan berbagai macam aspek kehidupan bermasyarakat, berebangsa dan bernegara, serta sifatnya berlintas negara, terorganisir, dan memiliki jaringan luas yang juga memiliki tujuan tertentu.

Oleh karena itu dalam proses pemberantasannya membutuhkan suatu cara khusus, dilakukan secara khusus, tersusun, terencana, terpadu, terarah, dan harus adanya kesinambungan penindakan serta dalam penanganannya mengacu dan berdasar pada Pancasila yang berkedudukan sebagai landasan idiil dan Undang-Undang Dasar Negara Republik Indonesia Tahun 1945 yang berkedudukan sebagai landasan operasional. Sehingga, sebagai pemenuhan dan untuk menjawab atas penjaminan perlindungan dan kepastian hukum maka dibentuklah landasan hukum yang kukuh untuk memenuhi perkembangan dan kebutuhan hukum dalam masyarakat dalam upaya pemberantasan tindak pidana terorisme tersebut (Dwi Sarwono, 2019).

Dalam Undang-Undang Nomor 48 Tahun 2009 tentang Kekuasaan Kehakiman. Dalam undang-undang ini disebutkan bahwa yang menjadi pelaku kekuasaan kehakiman adalah Mahkamah Agung dan badan peradilan di bawahnya sebagaimana tercantum 
dalam Undang-Undang Dasar Negara Republik Indonesia Tahun 1945. Kekuasaan Kehakiman merupakan salah satu sumber hukum acara pidana, adanya asas fundamental berhubungan dengan hak-hak tersangka yakni asas praduga tak bersalah yang berbunyi: Setiap orang yang disangka, ditangkap, dituntut, dan atau dihadapkan di muka Pengadilan wajib dianggap tidak bersalah sebelum diadakan putusan yang menyatakan kesalahannya dan telah memperoleh kekuatan hukum tetap.

Asas praduga tak bersalah dijadikan sebagai aturan atau norma yang isinya berupa ketentuan yang wajib dilaksanakan oleh aparat penegak hukum (APH) untuk memperlakukan tersangka atau terdakwa seperti halnya orang yang tidak bersalah atau dengan maksud lain asas praduga tak bersalah adalah aturan tata kerja (pegangan dan pedoman) bagi para badan penegak hukum dalam memberi perlakuan dan bagaimana memperlakukan tersangka atau terdakwa dengan mengesampingkan praduga atas bersalahnya. Ditetapkan dan diterapkannya asas praduga tak bersalah sangat penting dalam proses pelaksanaan peradilan pidana sebagai wujud penghargaan dan penghormatan terhadap hak asasi manusia yang sangat dijunjung dan dihormati serta ditegakkan di Indonesia. Berdasarkan asas tersebut, sudah sepantasnya apabila seseorang yang disangka atau didakwa melakukan suatu tindak pidana, maka wajib ditempatkan sesuai harkat dan martabatnya sebagai manusia (Achmad Budi Waskito, 2018).

Pemberian interpretasi atau makna mengenai hak-hak asasi, selalu diletakkan dalam kerangka pandangan hidup, cita-cita bangsa dan negara serta budaya bangsa yang bersangkutan. Bagi bangsa Indonesia telah dicantumkan hak asasi manusia atau yang disebut hak dan kewajiban warga negara dalam Undang-Undang Dasar Negara Republik Indonesia Tahun 1945 yang bersumber pada Pancasila. HAM merupakan hak yang paling mendasar yang secara kodrati telah melekat pada diri manusia sejak dalam kandungan hingga lahir di dunia, bersifat universal dan langgeng, maka dari itu harus dihargai, dihormati, dilindungi, dipertahankan, dan tidak boleh diabaikan, dikurangi atau dirampas oleh siapapun atas dasar apapun. HAM (human rights) yang secara universal diartikan sebagai those rights which are inherent in our nature and without which we cannot live as human being: penyusunan dan pengakuannya telah diperjuangkan dalam waktu yang lama oleh masyarakat dunia.

Pada awalnya banyak yang beranggapan bahwa HAM merupakan sebuah produk liberal atau rumusannya dari bangsa barat, orang yang berbicara HAM adalah penganut liberalisme bahkan ada yang menganggap sebagai generasi baru komunisme, tetapi pandangan tersebut sekarang telah berubah. Sekarang ini Pandangan tentang HAM sudah berkembang dan semakin pesat kemajuannya, HAM telah disambut positif dengan tangan terbuka bukan lagi dalam pengertian atau pandangan dari kaum Liberalis maupun Komunis, melainkan sebuah terobosan dan pandangan yang universal yang menjadi tuntutan kebutuhan bagi masyarakat dunia.

Bahkan hingga sekarang ini, hal tersebut masih berlangsung, dengan bermacam aspek permasalahan yang timbul karena berbagai penafsiran yang saling berkaitan di dalamnya. Kewajiban dan tanggung jawab Pemerintah disebutkan dalam Pasal 71 Undang-Undang Nomor 39 Tahun 1999 tentang Hak Asasi Manusia, yaitu: Pemerintah 
wajib dan tanggung jawab menghormati, melindungi, menegakkan, dan memajukan HAM yang diatur dalam Undang-Undang ini, peraturan perundang-undangan lain dan hukum Internasional tentang HAM yang diterima oleh Negara Republik Indonesia.

Negara telah bertanggung jawab terhadap tersangka tindak pidana dengan memberikan jaminan melalui undang-undang sebagai wujud perwujudan dari proses penegakan hukum dari hak asasi manusia. Dalam undang-undang pemberantasan tindak pidana terorisme dimuat hal terkait pemberian lindungan hak-hak untuk tersangka tindak pidana terorisme. Pemberian perlindungan hak-hak bagi tersangka tindak pidana terorisme dengan menempatkan tersangka atau terdakwa sesuai dengan harkat dan martabatnya sebagai manusia, menghormati bahwa ia juga merupakan manusia yang memiliki hak yang harus dipatuhi dan dihormati disamping ia harus membayar konsekuensi atas kesalahan yang telah diperbuat. Sebagai bentuk keseimbangan, pemberian perlindungan dalam hal pemenuhan hak dan kewajiban sebagai subjek hukum dijamin oleh negara. Tidak bisa dipungkiri, bahwa negara telah mengupayakan dan mengusahakan bentuk-bentuk dari perlindungan hak-hak bagi tersangka atau terdakwa tersebut melalui ditetapkannya peraturan perundang-undangan yang mengatur juga sebagai payung hukum serta penegakan yang dilakukan dengan tegas dan sebagaimana mestinya.

\section{Metode Penelitian}

Dalam pelaksanaan penelitian, peneliti menggunakan metode deskriptif dengan pendekatan penelitian kualitatif yaitu melukiskan atau menggambarkan keadaan objek dan subjek, baik lembaga, masyarakat, dan lain sebagainya, serta berdasarkan pada hasil observasi yang dilakukan serta memberikan pendapat terhadap penemuan dan dihubungkan dengan konsep teori yang relevan. Definisi penelitian kualitatif menurut Kirk dan miller adalah sebuah tradisi tertentu dalam dunia ilmu pengetahuan sosial yang secara mendasar bergantung dari pengamatan yang dilakukan manusia baik dalam kawasan maupun dalam peristilahannya. Sedangkan, pendapat dari David Williams, penelitian kualitatif merupakan sebuah metode pengumpulan data pada suatu latar alamiah, dengan menggunakan metode alamiah, dan dilakukan oleh orang atau peneliti yang tertarik secara alamiah. Dari definisi ini memberikan gambaran bahwa penelitian kualitatif mementingkan sudut pandang ilmiah, dan metode ilmiah (Moleong, 2017).

Bungin menyatakan bahwa pendekatan penelitian kualitatif diperlukan untuk menemukan jawaban logis pada setiap fenomena yang terjadi dalam kurun waktu tertentu. Penelitian kualitatif melibatkan pengumpulan informasi tentang pengalaman pribadi, introspeksi, kehidupan, cerita, wawancara, observasi, sejarah, interaksi dan teks visual yang merupakan momen penting dan bermakna dalam kehidupan masyarakat (Bungin, 2018).

Menurut penjelasan diatas maka penelitian kualitatif digunakan untuk menggambarkan hasil penelitian secara terstruktur dengan menggunakan fakta-fakta yang ada. Data-data yang diperoleh oleh penelitian kualitatif akan diolah dalam bentuk rangkaian dan susunan kata-kata atau sebuah pernyataan bukan dalam bentuk angka- 
angka. Alasan penulis menggunakan tipe deskriptif karena tipe ini mampu menggambarkan fakta-fakta mengenai efektivitas program pembinaan kemandirian dalam rangka mencapai tujuan pemasyarakatan.

\section{Hasil dan Pembahasan}

\section{Efektifitas pembinaan dan pemenuhan hak bagi narapidana terorisme di Lembaga Pemasyarakatan}

Hingga dewasa ini, sistem pemasyarakatan yang berlaku secara historis dan konseptual sangat kontras hingga bisa dikatakan bertolak belakang dengan sistem yang berlaku pada saat masa sistem kepenjaraan. Sistem pemasyarakatan menerapkan asas menempatkan tahanan, narapidana, anak negara dan klien pemasyarakatan sebagai subjek yang dipandang sebagai pribadi dan warga negara biasa serta dihadapi dengan memberikan pembinaan dan bimbingan bukan dengan latar belakang pembalasan. Perlu adanya peningkatan dalam pembinaan dan bimbingan melalui pendekatan secara mental, jasmani dan kedisiplinan.

Secara umum pembinaan pada narapidana mempunyai tujuan agar mereka dapat kembali menjadi manusia yang seutuhnya sebagaimana sesuai dengan yang menjadi arah pembangunan nasional yang melalui jalur agama dengan memantapkan dan memperteguh iman, berpegah teguh pada agama menjadi pondasi pertama dan yang utama dalam pelaksanaannya. Setiap agama pasti mengajarkan pada umat-Nya bahwa pasti ada perintah yang harus dikerjakan dan ada larangan yang harus dihindari. Tuhan mengajarkan pada seluruh umat, tidak ada dan tidak dibenarkan bahwa tindakan dan kegiatan merusak, melukai, menyakiti orang lain adalah benar. Pendekatan agama ini merupakan bentuk dari ketahanan mental bagi narapidana. Membina narapidana agar mampu berintegrasi dan berbaur secara wajar di dalam kehidupan kelompok yang ada di Lapas (selama menjalani masa pemidanaan) dan kehidupan yang lebih luas (masyarakat) nantinya setelah usai dan berakhirnya masa pemidanaannya.

Pembinaan dan pembimbingan dengan pendekatan jasmani dan kedisiplinan ditujukan agar narapidana keluar dan terbebas dengan membawa bekal keahlian, keterampilan sebagai modal agar dapat diterima oleh masyarakat disekitarnya.

Pembinaan narapidana secara khusus dimaksudkan dengan tujuan agar selama masa pembinaan dan sesudah selesai akan melanjutkan menjalani masa depannya :

1. Berhasil dengan memantapkan kembali harga diri, percaya diri, mendapat kepercayaan kembali dari masyarakat serta mempunyai sikap optimis, respektif dan inovatif di masa yang mendatang;

2. Berhasil dengan maksud telah memperoleh wawasan dan pengetahuan, minimal keahlian/keterampilan sebagai bekal atau modal yang dapat digunakan agar mampu hidup secara mandiri dapat memperbaiki penghidupannya dan ikut berperan aktif dalam kegiatan pembangunan nasional;

3. Mampu menunjukkan dan membuktikan sebagai manusia yang berhasil sebagai manusia yang patuh akan hukum tercermin dan terlihat dari sikap dan 
perilakunya yang tertib dan disiplin serta mampu menggalang solidaritas dan kesetiakawanan sosial;

4. Berhasil tertanamnya jiwa yang semangat terhadap pembangunan nasional dan bangga terhadap bangsa dan negara.

Seiring meningkatnya angka kasus pidana saat ini, ditambah catatan narapidana teroris, maka perlu dilakukan pendekatan dan pola pembinaan khusus. Kegiatan yang diberikan tidak hanya semata-mata dimaksudkan sebagai kegiatan pengisi waktu luang atau tidak sekedarnya saja. Kegiatan ini ditujukan juga sebagai kegiatan menyibukkan diri dan mengalihkan perhatian agar terhindar dari pemikiran-pemikiran yang negatif atau bahkan membawa pengaruh besar, namun harus juga lebih dititikberatkan pada penciptaan kondisi kegiatan pembinaan yang kondusif (M. Ali 2012).

Pembinaan yang diberikan pada narapidana teroris harus sesuai dengan ketentuan dan aturan yang berlaku, yaitu Peraturan Pemerintah Republik Indonesia Nomor 99 Tahun 2012 tentang Perubahan Kedua Atas Peraturan Pemerintah Nomor 32 Tahun 1999 tentang Syarat dan Tata Cara Pelaksanaan Hak Warga Binaan Pemasyarakatan yang memberatkan sisi keamanan, ketertiban umum dan rasa keadilan masyarakat. Secara spesifik dan lebih mendalam lagi kejahatan terorisme merupakan kejahatan internasional dan extra ordinary crime. Extra ordinary crime disebut sebagai kejahatan besar karena membawa dampak negatif dan multidimensional terhadap ekonomi, politik, sosial, dan budaya. Pemerintah mendefinisikan kejahatan terorisme sebagai kejahatan terhadap peradaban dan perkembangan manusia, kejahatan kemanusiaan, serta salah satu ancaman yang genting dan serius bagi kedaulatan sebuah negara. Terorisme dikatakan sebagai kejahatan internasional karena telah mengancam ketertiban, keamanan, mengganggu kedamaian, dan membawa dampak kerugian besar bagi kesejahteraan masyarakat. Oleh karenanya, pemberantasan tindak pidana terorisme harus diberantas dengan strategi yang terencana, tersusun, terarah, dan berkesinambungan agar dapat memberantas jaringan terorisme yang terorganisir sampai ke akar-akarnya, agar tercapainya tujuan utama yaitu terjaganya hak asasi publik.

Dari pendefinisian tersebut dapat diperoleh bahwa secara linier antara pemberantasan kejahatan terorisme berhubungan dengan cita-cita bangsa Indonesia yang tertera dalam Pembukaan Undang-Undang Dasar (UUD) Negara Republik Indonesia Tahun 1945 alinea ke- IV yaitu untuk melindungi segenap bangsa Indonesia dan seluruh tumpah darah Indonesia, memajukan kesejahteraan umum, mencerdaskan kehidupan bangsa, serta melaksanakan ketertiban dunia. Jelas sudah bahwa secara holistik segala macam bentuk kejahatan kekerasan termasuk juga terorisme itu mengganggu pewujudan dan pencapaian dari cita-cita bangsa yang kemudian akan menyebabkan terjadinya gangguan pada kepentingan nasional negara Indonesia mulai dari aksi penekanan, teror, dan merenggut atau menghilangkan nyawa.

Pemberian penekanan dalam hal pemenuhan hak narapidana teroris tersebut tidak berdiri sendiri dengan konsep sistem pemasyarakatan, sesuai dengan amanat dari Undang-Undang Nomor 12 Tahun 1995 tentang Sistem Pemasyarakatan Adanya konsep tersebut sebagai suatu tatanan terkait arah dan batas serta langkah pembinaan WBP 
menurut Pancasila yang dilaksanakan secara terpadu antara pembina, yang dibina dan masyarakat dalam rangka peningkatan kualitas WBP supaya dapat menyadari kesalahan, melakukan perbaikan diri dan tidak mengulangi tindak pidana. Tujuannya tidak lain supaya warga binaan pemasyarakatan tersebut dapat diterima kembali oleh lingkungan masyarakat sekitar, ikut serta dalam kegiatan pembangunan dan dapat hidup sewajarnya sebagai warga teladan.

Secara umum binaan dan bimbingan yang diberlakukan untuk narapidana teroris dapat melancarkan menggunakan pendekatan pembinaan kepribadian yang di dalamnya mencakup keagamaan, pancasila, hukum, kesadaran bernegara, konseling, olahraga dan kesenian yang bersifat edukatif. Hal tersebut berdasar pada pemahaman bahwa narapidana teroris yang berada di dalam suatu sistem pemasyarakatan harus dipulihkan dan dikembalikan, baik secara psikologis maupun dari segi attitude sebagai pribadi atau warga negara yang mempunyai potensi serta bias berperan aktif dalam pembangunan bangsa. Pendekatan berikutnya ialah pembinaan dengan pemberian pemberdayaan dalam wujud pembinaan kemandirian yaitu sebuah upaya untuk memberikan bekal keterampilan-keterampilan yang dapat meningkatkan kualitas narapidana teroris sebagai bekal dalam memenuhi hidup dan kehidupannya di kemudian hari. Pemberian pendekatan pembinaan kepada narapidana teroris, baik yang berupa pembinaan kepribadian maupun kemandirian harus sejalan dan beriringan dengan tujuan dari sistem pemasyarakatan yang menjadi fasilitator dan rehabilitatif dalam proses perubahan sikap, mental dan perilaku narapidana teroris menuju kehidupan yang positif melalui pendekatan secara agama, ekonomi, dan sosial budaya. Tidak hanya itu, pembinaan dengan pengetahuan agama yang damai dan toleran serta wawasan kebangsaan dalam lingkup Negara Kesatuan Republik Indonesia tersebut dapat memberikan pencerahan pemikiran kepada narapidana teroris.

Pola perlakuan yang diberikan kepada narapidana teroris selama ini belum spesifik, polanya masih sama dengan perlakuan narapidana pada umumnya yang bukan Napiter. Dalam realisasinya program Deradikalisasi hanyalah sebatas pengakuan dan ikrar tertulis yang berisi tidak mengulangi perbuatan dan mengakui NKRI sebagai negaranya. Sedangkan pada Pembinaan Napiter telah dibuat dan ditetapkan pedoman pembinaan yang dirumuskan oleh direktorat jenderal pemasyarakatan dalam Keputusan Direktur Jenderal Pemasyarakatan Kementerian Hukum dan Hak Asasi Manusia RI No: PAS172.PK.01.06.01. Tahun 2015 Tentang Standar Pembinaan Narapidana Teroris. Program pembinaan terhadap narapidana teroris umumnya lebih banyak dibandingkan dengan program pembinaan narapidana lain, seperti adanya Program Profiling and Assessment. Program profiling ini merupakan kegiatan pencatatan perilaku, baik individu maupun kelompok, dan melakukan analisis terhadap karakteristik psikologis guna menafsir dan memprediksi kemampuan individu terhadap bidang tertentu. Umumnya, kegiatan profiling ini berupa: pencatatan identitas, latar belakang kasus dan perilaku dengan tujuan mendapat informasi yang komprehensif sebagai program penempatan dan pembinaan. 
Dari sisi petugas, profiling bertujuan untuk mengetahui pandangan idealisme seorang narapidana teroris terkait konsep Jihad yang mana doktrin dari konsep jihad yang didapatkan dan diterima oleh seorang teroris adalah dianggapnya sebuah konsep yang benar-benar diturunkan oleh Tuhannya sehingga ia beranggapan bahwa dengan dia rela meninggalkan jihad dengan ikut bunuh diri di dalamnya merupakan suatu hal yang benar padahal itu hal yang melawan dan menentang hukum yang berlaku, mengetahui tingkat Radikalisme narapidana teroris, melakukan pemetaan jaringan berdasarkan faksi dan aliran narapidana teroris, menentukan penempatan narapidana teroris di Lapas sehingga dapat mencegah gangguan kamtib, penempatan narapidana teroris dengan melihat aspekaspek yang menjadi pertimbangan yaitu tingkat risiko dan radikalismenya. Dalam rangka upaya untuk mencegah, mengantisipasi, dan menangani adanya gangguan keamanan dan ketertiban (kamtib) dalam Lapas maka sangat diperlukan usaha pendeteksian dini yang dilakukan oleh petugas secara rutin dan periodik.

Selanjutnya, Program Assessment adalah serangkaian cara dan proses guna mengumpulkan umpan balik tentang pembinaan yang didapat narapidana terori. Assessment ini dapat dilaksanakan di awal, di akhir (sesudah) maupun saat pembinaan berlangsung. Assessment yang diberikan dapat berupa tes maupun non tes. Contoh assessment non tes adalah interview, observasi, pemantauan terhadap tindakan dan lainlain. Hasil dari assessment yang telah diberlakukan akan digunakan dalam kepentingan pengambilan keputusan. Metode selanjutnya yang digunakan adalah assestment Resiko dan assessment kebutuhan bagi Napiter dan Klien Bapas kasus Terorisme. Dengan adanya Assessment tersebut, dapat diketahui antara lain resiko pengulangan tindak pidana Terorisme, penilaian atas faktor-faktor kebutuhan atau Criminogenic Napiter, serta pedoman dalam menyusun program pembinaan.

Program Pembinaan lain yang diberikan berupa: program kesadaran beragama, program konseling psikologi, program kesadaran hukum, program kesadaran berbangsa dan bernegara, program kemampuan intelektual. Pemberian program pembinaan ini adalah suatu bentuk usaha dan usaha negara dalam menanggulangi paham-paham dan ideologi yang menyimpang di masyarakat yang berakar Radikalisme dan Terorisme. Dalam penanganan Terorisme, hal yang paling utama adalah anti terorisme maupun kontra terorisme. Jika semua program dapat berjalan dengan baik dan memiliki arah, tentunya tujuan dari pembinaan Napiter dapat terlaksana dan mendapatkan hasil yang maksimal sesuai dengan misi pemasyarakatan dengan Deradikalisasi. Berikut indikatorindikator yang dapat dijadikan patokan dari sebuah keberhasilan Program pembinaan deradikalisasi bagi Narapidana teroris (Napiter) di dalam Lembaga Pemasyarakatan adalah:

1. Narapidana teroris mempunyai rasa tanggung jawab sosial, baik saat berada di dalam maupun di luar Lembaga Pemasyarakatan yang ditunjukkan dengan kesanggupan berperan di dalam lingkungan sekitar pada masa Reintegrasi.

2. Napiter mempunyai kemampuan dan keterampilan sosial, bilamana diasah dan diterapkan dengan sebagaimana mestinya maka kedepannya mereka dapat menyatu dan bekerja sama dengan orang lain di luar kelompoknya di dalam 
Lembaga Pemasyarakatan maupun mampu bergaul secara baik ditengah masyarakat, sehingga mantan Napiter tersebut dapat mengembalikan dan memperbaiki hidup dan kehidupannya menjadi yang lebih baik bahkan dari sebelumnya.

3. Napiter sebenarnya mempunyai kemampuan psikis dasar yang pada akhirnya membuat mereka sadar dan mengakui kesalahannya, adanya kemauan untuk meningkatkan dan mengembangkan diri, menyadari juga menerima keberadaan perbedaan kelompok, kemauan untuk membiasakan diri bersikap dan berpikiran kritis, logis, dan toleran sebagai wujud penyesuaian diri.

4. Napiter mampu menerapkan dan mengamalkan ajaran agama melalui praktik yang memperlihatkan adanya rasa sayang terhadap sesama manusia, dengan menciptakan kerukunan dan perdamaian di masyarakat secara bersama-sama dan mau menjalankan sholat berjamaah dengan narapidana lainnya di masjid Lembaga pemasyarakatan.

5. Napiter tidak memaksakan paham-paham yang dianutnya dan kehendaknya.

6. Napiter mempunyai kemampuan dan keterampilan dasar atau kemandirian yang dapat dimanfaatkan untuk memperoleh pendapatan atau nafkah untuk menyambung hidup.

7. Napiter sudah mempunyai kesadaran hukum, wawasan kebangsaan yang baik serta mengaku dan melakukan ikrar setia kepada NKRI. Apabila indikatorindikator diatas telah ditunjukkan oleh seorang mantan Narapidana Terorisme (Napiter) maka penerapan program deradikalisasi kepada Napiter dapat dikatakan berhasil, dan dapat dikatakan efektif dari pola pembinaan napiter tersebut berdasarkan standar pembinaan narapidana teroris. Rentang waktu yang dibutuhkan dalam pembinaan di dalam Kep Dirjen Pas tersebut diselaraskan dengan masa pidana yang dijalani dengan berdasarkan tahapan-tahapan dalam proses pemasyarakatan. Akan dilakukan tahapan evaluasi disetiap akhir rangkaian pelaksanaan program pembinaan yang diberikan pada Napiter sebagai bentuk pertimbangan dalam melaksanakan program pada tahapan selanjutnya:

8. Tahap awal, yaitu pada 0 s.d 1/3 masa pidana. Yang terdiri dari masa pengenalan lingkungan, profiling, assessment risiko, Litmus Bapas, Kesadaran dalam; beragama, mematuhi hukum, berbangsa dan bernegara, kemampuan intelektual, konseling psikologi, kesehatan raga dan Litmas evaluasi.

9. Tahap Lanjutan I, pada 1/3 s.d 1/2 masa pidana. Tahap ini terdiri dari: profiling, assessment kebutuhan, Litmas, kesadaran beragama, kesadaran dalam; mematuhi hukum, berbangsa dan bernegara, kemampuan intelektual, konseling psikologi, kesehatan raga, pembinaan kemandirian dan Litmas evaluasi.

10. Tahap Lanjutan II, pada $1 / 2$ 2/3 masa pidana. Meliputi: profiling, Assessment kebutuhan, Litmas, kesadaran dalam melaksanakan kegiatan keagamaan, kemampuan intelektual, kesadaran akan berabangsa dan bernegara, konseling psikologi, kesehatan jasmani, pembinaan kemandirian dan Litmas Evaluasi. 
11. Tahap akhir, yaitu pada $2 / 3$ s.d bebas masa pidana. Pada tahap ini terdiri dari; profiling, Assessment kebutuhan, Litmas, kesadaran dalam; melaksanakan kegiatan keagamaan, mematuhi hukum, berbangsa dan bernegara, kemampuan intelektual, konseling psikologi, kesehatan jasmani dan Litmas evaluasi. Ketaatan dan kepatuhan, serta taat atau tidaknya seorang Napiter dalam mengikuti dan menjalani setiap program dapat dijadikan sebuah pertimbangan untuk diajukan guna mendapat remisi dan pembebasan bersyarat, tentunya tetap sesuai dengan prosedur yang telah ditetapkan. Program pembinaan lain di Lapas yang tidak diatur dalam standar pembinaan Napiter tersebut, akan tetap dilaksanakan sebagai program pelengkap.

Sebagai petunjuk UPT Pemasyarakatan dalam mengadakan pembinaan Napiter, pada tahun 2015, Direktorat jenderal pemasyarakatan telah menerbitkan Keputusan Dirjen Pemasyarakatan No: Pas -172.PK.01.06.01 Tahun 2015 Tentang Standar Pembinaan Narapidana Teroris. Standar Pembinaan Napiter tersebut yang secara umum terdiri atas beberapa program sebagai berikut:

1. Program masa pengenalan lingkungan

2. Program profiling

3. Program Assessment Risiko dan Assessment Kebutuhan

4. Program Litmus Bapas

5. Program kesadaran beragama

6. Program kesadaran hukum

7. Program kemampuan intelektual

8. Program kesadaran berbangsa dan bernegara

9. Program Konseling

10. Program kesehatan jasmani

11. Program pembinaan kemandirian.

Dalam menjaga dan mempertahankan stabilitas Negara, pemidanaan terhadap para pelaku terorisme merupakan kajian penting. Oleh karena itu, Lembaga Pemasyarakatan berperan penting dalam membina Napiter agar tidak mengulangi perbuatannya. Lapas memiliki dua peranan penting yakni Reedukasi dan Resosialisasi Napiter. Lapas sebagai ujung tombak pelaksanaan asas pengayoman yang mana menjadi tempat untuk mencapai tujuan sistem pemasyarakatan melalui rehabilitasi dan reintegrasi. Program Rehabilitasi wajib dilakukan oleh Lembaga pemasyarakatan. Sedangkan, untuk Program reintegrasi dapat dilakukan di dalam Lapas maupun di luar Lapas. Rehabilitasi dan Reintegrasi menjadi pembinaan yang dilakukan Napiter guna memutus mata rantai kejahatan bermotif Terorisme melalui penanaman nilai-nilai yang diterapkan di dalam Lapas. Sehingga ketika ia kembali ke masyarakat, ia tidak lagi tergabung dalam jaringan terorisme. Selain itu, tujuan lainnya ialah guna menghilangkan paham Radikalisme yang telah tertanam dalam diri mereka, yakni ajaran yang dianut teroris (Anwar, 2013).

Ruang lingkup pembinaan narapidana teroris mengacu pada PP No. 31 Tahun 1999 tentang Pembinaan dan pembimbingan Warga binaan pemasyarakatan, yang bertujuan meningkatkan kualitas ketaqwaan, intelektual, sikap dan tindakan, profesional, 
kesehatan jasmani dan rohani warga binaan pemasyarakatan, melalui pembinaan kepribadian, kemandirian serta kesadaran berbangsa dan bernegara. Terdapat perlakuan khusus terhadap pembinaan narapidana teroris, baik dari sisi pengawasan, pembinaan dan pengamanan.

Lembaga Non Kementerian yang bertanggung jawab dalam penanganan Terorisme di Indonesia atau yang kita kenal dengan Badan nasional penanggulangan terorisme (BNPT) telah menggunakan strategi Deradikalisasi sebagai bentuk penanggulangan Terorisme, serta menjadi bentuk soft approach atau pendekatan yang komprehensif, persuasif, penuh sikap afeksi dan perlakuan halus. Dalam usaha menanggulangi kasus tersebut, BNPT menjalin kerja sama dengan pihak-pihak lainnya mulai dari Kepolisian, Lembaga Pemasyarakatan, Kementerian agama, KemenKokesra, Ormas dan lain sebagainya. Program Deradikalisasi yang dilakukan BNPT ini terdiri dari:

1. Re-edukasi yang merupakan upaya penangkalan paham radikalisme dengan memberikan pemahaman kepada masyarakat terkait paham radikal supaya tidak terjadi persebaran paham radikal di tengah masyarakat. Re-edukasi yang berlaku untuk Napiter dilakukan dengan cara memberikan pemahaman terkait doktrin dan paham yang menyimpang yang berisi ajaran kekerasan sehingga mereka dapat tersadar bahwa melakukan kekerasan seperti bom bunuh diri bukanlah jihad. Mereka menganggap jihad diidentikkan dengan aksi terorisme.

2. Rehabilitasi dilakukan dengan dua pembinaan yakni pembinaan kemandirian dan kepribadian. Pembinaan kemandirian dilakukan dengan melatih keterampilan dan keahlian dalam diri Napiter sebagai bekal untuk hidup di masyarakat setelah mereka keluar dari Lembaga Pemasyarakatan. Sedangkan Pembinaan kepribadian dilakukan melalui pendekatan, ceramah keagamaan yang lurus, tidak menyimpang, berdialog dengan Napiter agar bisa merubah mindset mereka yang sudah terkontaminasi paham-paham Radikal.

3. Untuk memudahkan Napiter dalam berbaur setelah keluar Lapas, BNPT juga membimbing mereka dalam bersosialisasi dan menyatu kembali dengan masyarakat (Resosialisasi dan Reintegrasi).

\section{Apa saja kendala dalam pembinaan dan pemenuhan hak narapidana teroris}

Meskipun pembinaan Napiter sudah dilaksanakan sesuai dengan memperhatikan dan mempedomani pada Kep Dirjen Pas Kementerian Hukum dan HAM RI No: PAS 172.PK.01.06.01.Tahun 2015 Tentang Standar Pembinaan Narapidana Teroris, Namun tidak serta merta menjadikan pembinaan Napiter tersebut berjalan mulus tanpa adanya hambatan dan rintangan sehingga tujuan Pemasyarakatan terutama untuk Napiter dengan proses deradikalisasinya dapat berjalan lancar, Setidaknya ada banyak kendala yang dihadapi baik oleh petugas, stakeholder terkait maupun dihadapi oleh Napiter itu sendiri. Beberapa kendala yang dihadapi tersebut diantaranya: Pertama, sumber daya manusia. Untuk membina seseorang yang sudah terpapar dengan paham Radikalisme yang bersumber pada pemahaman yang salah 
tentang ajaran agama terutama konsep Jihad, Maka diperlukan seorang Pembina yang menguasai keagamaan secara matang, yang memiliki ilmu agama yang sangat tinggi, Sehingga dapat dengan mudah untuk mengarahkan dan membimbing Napiter ke jalan yang lurus dan tidak menyimpang dari ajaran agamanya. Tentu saja keterampilan petugas atau Pembina ini bukan hanya yang mempunyai ilmu agama yang luas saja, Tapi juga harus menguasai ilmu-ilmu yang lain yang diperlukan dan berkompetensi dalam ilmu tersebut seperti Ilmu kebangsaan dan kenegaraannya, ilmu hukumnya, ilmu sosial budaya, ilmu politik dan lain sebagainya.

Sementara yang berada di lapangan saat ini, SDM Pembina Napiter ini bukan yang berkompetensi. Secara akademik untuk Pembina hanya lulusan setingkat SMA atau paling tinggi lulusan Sarjana, Padahal yang harus dihadapi dan dibina adalah Narapidana yang secara Paham sangat kuat dan perlu diluruskan dengan pemahaman ilmu yang lebih dalam. Dalam standar pembinaan Napiter tersebut dijelaskan untuk tiap tahap misalnya program profiling itu dibutuhkan kompetensi pelaksana lulusan strata 1 atau sarjana, untuk program kesadaran beragama dibutuhkan kompetensi pelaksana minimal sarjana agama. Program kesadaran hukum diperlukan minimal kompetensi pelaksana Sarjana Hukum. Itulah realita di lapangan SDMnya rata-rata tidak sesuai dengan kompetensi pelaksana yang di perlukan dalam pembinaan Napiter. Kedua, sarana dan prasarana yang kurang memadai. Sarana adalah segala sesuatu (bisa berupa syarat atau upaya) yang dapat digunakan sebagai alat atau media untuk meraih tujuan. Sedangkan prasarana diartikan sebagai segala sesuatu yang menjadi penunjang utama terlaksananya suatu proses (usaha, pembangunan, proyek, dsb). Secara umum, yang dimaksud dengan sarana dan prasarana adalah seperangkat alat yang berguna untuk kegiatan tertentu. Alat tersebut bisa berupa alat utama atau alat pembantu proses kegiatan agar dapat mencapai tujuan dari suatu kegiatan. Sebenarnya sarana dan prasarana bukan hanya meliputi seperangkat alat atau barang saja, tapi bisa juga suatu tempat atau ruangan untuk proses kegiatan.

Sarana dan prasarana yang digunakan dalam pembinaan Napiter berbeda-beda tergantung program pembinaan yang dilaksanakan sebagai contoh pada program profiling sarana yang digunakan seperti: Komputer, Alat tulis kantor, alat perekam dan buku catatan, Prasarananya yang diperlukan yaitu ruang wawancara pada program pembinaan lainnya sarananya diantaranya: sound system, buku modul, buku tentang kebangsaan dan bernegara, peralatan olahraga, dan lain sebagainya. Untuk prasarana pembinaan yang diperlukan diantaranya: tempat ibadah, tempat olahraga, ruang bengkel kerja, lahan dalam Lapas, ruang konseling, ruang serba guna, perpustakaan, Ruang pendidikan dan lain sebagainya. Dari sarana dan prasarana yang diperlukan untuk pembinaan napiter, tidak semua Lapas dan Rutan terdapat sarana dan prasarana tersebut, Sehingga hal tersebut menghambat dalam proses program pembinaan terhambat. Ketiga, masih adanya Lembaga pemasyarakatan yang melakukan pembinaan terhadap Napiter sama dengan membina Narapidana tindak pidana umum. Penempatan dan Pembinaan Napiter di Indonesia di sebar di beberapa Lapas dan Rutan. Data terakhir narapidana kasus terorisme yang sejumlah 519 dengan rincian: 502 napiter, 4 taher dan 
13 di luar Lapas melalui asimilasi deradikalisasi, yang tersebar luas di 26 kantor wilayah 87 unit pelaksana teknis (86 Lapas dan 1 Rutan) dan sudah NKRI sebanyak 143.

\section{Kesimpulan}

Sistem pemasyarakatan bertujuan untuk membentuk Warga Binaan Pemasyarakatan (WBP) supaya menjadi manusia sejati yang dapat menyadari kesalahan, mampu memperbaiki diri, dan tidak mengulang tindak pidana. Dengan demikian, WBP dapat diterima kembali di lingkungan masyarakat, berperan aktif dan ikut serta dalam pembangunan, hidup sewajarnya sebagai warga negara teladan.

Narapidana bukan hanya diposisikan sekedar sebagai objek, akan tetapi juga subjek dalam suatu proses pembinaan. Sasarannya mengembalikan narapidana kembali di tengah kehidupan masyarakat sebagai orang yang baik, berguna, dan bertanggung jawab (resosialisasi terpidana). Penjelasan dan definisi mengenai tindak pidana terorisme tertuang dalam Pasal 1 Ayat (2) Undang-Undang Nomor 5 Tahun 2018 Tentang Pemberantasan Tindak Pidana Terorisme.

Secara linier antara pemberantasan kejahatan terorisme berhubungan dengan citacita bangsa Indonesia yang tertera dalam Pembukaan Undang-Undang Dasar (UUD) Negara Republik Indonesia Tahun 1945 alinea ke-IV yaitu untuk melindungi segenap bangsa Indonesia dan seluruh tumpah darah Indonesia, memajukan kesejahteraan umum, mencerdaskan kehidupan bangsa, serta melaksanakan ketertiban dunia. Jelas sudah bahwa secara holistik segala macam bentuk kejahatan kekerasan termasuk juga terorisme itu mengganggu pewujudan dan pencapaian dari tujuan cita-cita bangsa. Pembinaan bagi Napiter yang bersifat khusus baik dalam pengawasan, pembinaan dan pengamanan termasuk dalam ruang lingkup pembinaan Napiter yang mengacu pada PP No. 31 Tahun 1999 tentang Pembinaan dan pembimbingan Warga Binaan Pemasyarakatan. 


\section{BIBLIOGRAFI}

Ali, Achmad, Menguak Tabir Hukum, and I I Cetakan Ke. 2008. "Ghalia Indonesia." Bogor Selatan, Edisi Kedua. Google Scholar.

Ali, Mahrus. 2012. "Dasar-Dasar Hukum Pidana, Sinar Grafika.” Google Scholar

Anwar, Yesmil, Adang, (2013), Kriminologi: Edisi Kedua, Refika Aditama, Bandung. Google Scholar.

Bakhri, Syaiful, (2014), Sistem Peradilan Pidana Indonesia, Dalam Perspektif Pembaruan, Teori, dan Praktik Peradilan. Pustaka Pelajar. Yogyakarta. Google Scholar.

Chazawi, Adami, (2002), Pelajaran Hukum Pidana Bagian I, Stelsel Pidana, Tindak Pidana, Teori-teori Pemidanaan \& Batas Berlakunya Hukum Pidana, RajaGrafindo Persada, Jakarta. Google Scolar.

Achmad Budi Waskito, (2018), "Implementasi Sistem Peradilan Pidana Dalam Perspektif Integrasi”, Jurnal Daulat Hukum, Vol. 1, No. 1 Maret 2018 Google Scholar.

Dwi Sarwono Bc.ip,S.H,M.Si (Kasubdit Intelijen Direktorat Keamanan Dan Ketertiban, Direktorat Jenderal Pemasyarakatan, Kementerian Hukum Dan HAM, dalam paparan "Petugas Pemasyarakatan Sebagai Subyek Yang Membutuhkan Perlindungan". Google Scholar.

Sumarwoto, dkk. Deradicalisation to Combat Terrorism: Indonesia and Thailand Cases, Sriwijaya Law Review, Volume 4 Issue 2 2020. Google Scholar.

International Crisis Group, (2007), Deradicalization and Indonesian Prisons, Asia Report, No. 42, 19 November 2007. Google Scholar.

Institute For Policy Analysis of Conflict (IPAC), (2013), Prison Problems: Planned And Unplanned Release Of Convicted Extremists In Indonesia, Jakarta: IPAC. Google Scholar.

M.K. Dermawan, (2001), "Pencegahan Kejahatan: Dari Sebab-Sebab Kejahatan Menuju Pada Konteks Kejahatan”, Jurnal Kriminologi Indonesia, Vol. 1 No. III, Juni 2001 Google Scholar. 